\title{
Lacrimal Gland Carcinoma TNM Finding v8
}

National Cancer Institute

\section{Source}

National Cancer Institute. Lacrimal Gland Carcinoma TNM Finding v8. NCI Thesaurus.

Code C140773.

A finding about one or more characteristics of carcinomas of the lacrimal gland,

following the rules of the TNM AJCC V8 classification system. There is no AJCC staging

system for carcinomas of the nasolacrimal sac. Lymphomas are staged according to the classification for ocular adnexal lymphomas. No stage groupings are currently

recommended for lacrimal gland carcinomas. (from AJCC 8th Ed.) 